\title{
VERBIVORMID B1- JA B2-TASEME KIRJALIKUS ÕPPIJAKEELES
}

\author{
Mare Kitsnik \\ Tallinna Ülikool
}

\begin{abstract}
Kokkuvõte. Eesti keele kui teise keele õppe ja hindamise aluseks oleva „Euroopa keeleõppe raamdokumendi" keeleoskustasemete funktsionaalsed kirjeldused vajavad täiendamist lingvistiliste kirjeldustega. Artiklis esitan eesti keele kui teise keele B1- ja B2-taseme verbivormide uurimise tulemused lähtuvalt CAF-triaadi dimensioonidest: keerukus ja täpsus. Tulemused olen saanud eesti vahekeele korpuses asuvate riiklike tasemeeksamite kirjutamisülesande soorituste uurimisel korpuse juhitud lähenemise ja DEMfad-mudeli abil. Olen selgitanud välja nii B1- kui ka B2-taseme sagedasemad verbivormid. Lähemalt olen vaadelnud verbi tahtma konstruktsioonide jaotuvust, sagedust ja täpsust B1- ja B2-taseme tekstides. Mõlemal tasemel esinevad sagedasemad verbivormid peamiselt isikulise tegumoe kindla kõneviisi olevikus ja lihtminevikus, tingiva kõneviisi olevikus ning infinitiividena. B1-tasemel esineb oluliselt rohkem kindla kõneviisi lihtminevikuvorme ning B2-tasemel kindla kõneviisi olevikuvorme, tingiva kõneviisi vorme ning infinitiivivorme. Nii B1- kui ka B2-tasemel esineb tahtma isikulise tegumoe kindlas ja tingivas kõneviisis ning mõlemal tasemel eelistatakse konstruktsioone tahan + infinitiivivorm ja tahaksin + infinitiivivorm. B2-tasemel suureneb verbi tahtma tingiva kõneviisi vormide sagedus ning kasvab konstruktsioonide täpsus.
\end{abstract}

Märksõnad: teise keele omandamine, eesti keel teise keelena, CAF-triaad, B1- ja B2-taseme lingvistiline kirjeldus, kirjalik õppijakeel, verbivormid

DOI: http://dx.doi.org/10.12697/jeful.2014.5.3.01

\section{Uurimuse taust ja uurimisküsimused}

Euroopa teiste keelte (K2) õpet on juba üle kümne aasta suuresti mõjutanud mahukas käsiraamat „Euroopa keeleõppe raamdokument” (CEFR, eesti keeles 2007). Raamdokument on loodud eesmärgiga anda kõigi teiste keelte õppijatele, õpetajatele, hindajatele ja teistele asjaosalistele ühtne arusaam keeleoskusest ja selle arenemisetappidest. Käsiraamatus on toodud kuueastmeline keeleoskustasemete süsteem: algaja keelekasutaja tase (A1 ja A2), iseseisva keelekasutaja tase (B1 ja B2) 
ning vilunud keelekasutaja tase ( $\mathrm{C} 1 \mathrm{ja} \mathrm{C} 2)$ koos iga taseme funktsionaalse keeleoskuse kirjeldusega. Funktsionaalse keeleoskuse all mõistetakse oskust keelt erisugustes suhtlussituatsioonides nii suuliselt kui kirjalikult kasutada, mitte ainult teadmisi keele struktuurist (Bachman ja Palmer 2010).

Lingvistiline pädevus on funktsionaalse keeleoskuse üks osa. Nii universaalses käsiraamatus nagu CEFR ei saa lingvistilist infot eriti spetsiifiliselt esitada. Raamdokumendis soovitatakse iga keele ekspertidel endil mõelda, missuguste grammatiliste üksuste, kategooriate, klasside, tarindite, protsesside ja seostega toimetulekuks peab õppija olema ette valmistatud (Raamdokument 2007: 119). Keeleuurijad ongi hakanud keeleoskustasemete lingvistilise sisu avamisega aktiivselt tegelema. Tasemeoskuste lingvistilise sisu empiiriliste uuringute eesmärgil on moodustatud mitteformaalne SLATE-võrgustik (Second Language Acquisition and Testing in Europe $)^{1}$, millesse koondunud eri riikide uurijad kasutavad sarnast uurimismetodoloogiat ja püüavad leida sarnasusi ja erinevusi eri keelte lingvistilistes profiilides keeleoskustasemete A1-C2 kaupa (Hulstijn jt 2010, Salamoura ja Saville 2010, Alanen jt 2010 ja Martin jt 2010).

Eesti keele puhulgi on raamdokumendi tasemekirjelduste konkretiseerimisega algust tehtud. Ilmunud on eesti keele põhised tasemekirjeldused: kõigepealt kaheksa autori koostöös valminud B1- ja B2-taseme käsiraamat (Hausenberg jt 2008) ning selle eeskujul A1-, A2- taseme käsiraamatud (Ilves 2008, 2010) ja C1-taseme käsiraamat (Kerge 2008). Nendes raamatutes on alustatud ka tasemete lingvistilise sisu kirjeldamist. Keelestruktuuride õpetamist seoses tasemetega on käsitlenud Kitsnik (2011). Kõik senised lingvistilised kirjeldused eesti keele kui K2 kohta on aga suures osas toetunud autorite kogemusele, intuitsioonile ja mõnesid üksikküsimusi käsitlevatele uuringutele. Meil on puudus teaduslikult tõestatud teadmistest selle kohta, kuidas eesti keele kui K2 omandamisprotsess tegelikult toimub: mis järjekorras ja mis keeleoskustasemel mingid keelestruktuurid ja sõnavara keelekasutusse ilmuvad ja millal ning mil määral need omandatakse. Teaduslik uurimine aitab kõigil asjaosalistel paremini mõista, mida on K2 õppijaile mis tasemel mõtet õpetada ja kuidas seda kõige tõhusamalt teha. Uuringud aitavad muuta ka suhtumist õppijakeelde - näiteks teadvustada, millised vead on madalamatel keeleoskustasemetel täiesti loomulikud ja mille poolest erineb ka teise keele kõrgtasemel valdajate keel

1 http://www.slate.eu.org/projects.htm (29.04.2014) 
emakeelekõnelejate omast. Lisaks selgub sellistes uurimustes, mis on eesti õppijakeeles universaalne (sarnane kõigile õppijakeeltele) ja mis keelespetsiifiline. Nii saame anda oma panuse ka kogu maailma teiste keelte uurimisse.

Käesoleva artikli aluseks võetud uurimus on osa suuremast uurimusest, mille eesmärgiks on leida eesti keele B1- ja B2-taseme kirjalikule keelekasutusele iseloomulikud lingvistilised tunnusjooned ning peamised deskriptorid, mis neid tasemeid eristavad. Artikli aluseks olnud uurimuses võrdlesin B1- ja B2-taseme kirjalikus õppijakeeles 1) verbivormide esinemist, 2) verbi tahtma konstruktsioone ning leidsin vastused järgmistele uurimisküsimustele:

- Millised on korduvate verbivormide esinemissagedused B1- ja B2-taseme kirjalikus õppijakeeles? Millised on tasemetevahelised sarnasused ja erinevused?

- Millised verbi tahtma konstruktsioonid esinevad B1- ja millised B2-taseme kirjalikus õppijakeeles? Millised on konstruktsioonide esinemissagedused, kui täpne on konstruktsioonide kasutus? Millised tasemetevahelised erinevused esinevad?

\section{Teooriaraamistik}

Uurimuse teoreetiliseks aluseks on kolm teise keele omandamist kirjeldavat dimensiooni: keerukus (ingl complexity), täpsus (ingl accuracy) ja sujuvus (ingl fluency) ehk nn CAF-triaad. Keerukust, täpsust ja sujuvust on uuritud juba alates 1970. aastatest, ühtseks kolmikuks ühendati need dimensioonid 1996. aastal (Skehan 1996). Nüüdseks on CAF-triaadi oluline roll keeleomandamise protsessis tõestatud (Skehan 2003, Larsen-Freeman 2006 ja Norris ja Ortega 2009) ning selle dimensioone uuritakse aktiivselt nii eraldi (Ellis 2008, Pallotti 2009, Housen ja Kuiken 2009 ja Skehan 2009 jt) kui vastastikuses koosmõjus (LarsenFreeman 2006, 2009, Spoelman ja Verspoor 2010 ja Norris ja Ortega 2009 jt). Kuigi CAF-triaadi mõistete defineerimisel ei valitse sugugi täielik üksmeel, on siiski võimalik anda CAFi dimensioonide definitsioonid, nii nagu neid praegu üldiselt mõistetakse. Käesolevas artiklis kirjeldatud uurimuses vaadeldakse B1- ja B2-taseme keerukust, täpsust ja sujuvust DEMfad-mudeli abil (Martin jt 2010, vt lähemalt pt 4).

Keerukust mõistetakse üldiselt vähemalt kahel eri viisil: kognitiivne keerukus ja lingvistiline keerukus. Kognitiivne keerukus (Hulstijn ja De Graaff 1994) näitab subjektiivset raskust, millega K2 õppija keele 
õppimise ja esitamise ajal keeleelemente töötleb ning see sõltub suurel määral õppijast. Lingvistiline keerukus on kognitiivse keerukuse üks oluline osa ja jaguneb omakorda süsteemi keerukuseks (mida väljendab leksika) ja struktuuri keerukuseks (mida väljendavad morfoloogia ja süntaks) (Bulté ja Housen 2012). Lingvistiline keerukus ei sõltu õppijast, vaid on määratud K2 formaalsete elementidega (keeleühikute vormid, tähendused, vormi ja tähenduse kattuvus jmt). Hawkins (2004) on keerukust defineerinud kui lingvistiliste vormide ja nende süntaktilist ja semantilist esinemist määravate omaduste hulka. Keerukus kasvab vormide hulga kasvuga, nendega seotud süntaktiliste ja semantiliste omaduste hulga suurenemisega ning kasutusala laienemisega. Süntaktilise keerukuse mõõtmisel on levinud näitajateks näiteks osalausete hulk T-üksuse (ingl T-unit) kohta ja kõrvallausete suhtarv. Leksikaalse keerukuse mõõtmise võimaluste üle on põhjalikult arutlenud Jarvis (2013).

Täpsus - selle mõiste sisu määratlemisel on uurijad kõige rohkem üksmeelel. Täpsust määratakse tavaliselt selle põhjal, kui palju K2 keelekasutus erineb normist. Üldine arusaam on, et norm võrdub emakeelekõneleja keelekasutusega ning kõrvalekaldeid sellest nimetatakse traditsiooniliselt veaks (Housen jt 2012). Küsitav on aga siiski, mis on normikohane keelekasutus: kas ainult standardkasutus või ka emakeelekõneleja mittestandardikohane keelekasutus või koguni mitte-emakeelekõneleja keelekasutus, kui see on mingis olukorras aktsepteeritav. CAFi uurimustes käsitletaksegi täpsust laiemalt, selle all mõistetakse keelekasutuse olukohasust ja aktsepteeritavust teiste suhtluses osalejate poolt (Ellis 2008 ja Pallotti 2009). Üldjuhul ei jagata täpsust mitmeks alaosaks ja seda mõõdetakse tavaliselt vigade arvu suhtega keeleühikute koguarvu, näiteks 100 sõna kohta või T-ühiku kohta (Housen jt 2012). Mõnikord jagatakse vigu siiski ka klassidesse (nt arusaamist takistavateks ja muudeks vigadeks) või vaadeldakse vigu mingite kindlate konstruktsioonide kasutamisel (Gunnarsson 2012).

Sujuvust määratletakse üldiselt kui keelekasutuse sarnasust loomuliku (ehk emakeelekõneleja) kasutusega mingis ajaühikus produtseeritud keeleühikute hulga, katkestuste arvu ja pikkuse, kordamiste hulga, eneseparanduste hulga jmt objektiivselt mõõdetavate suuruste poolest. Sujuvust mõõdetakse sagedamini suulistes tekstides (Skehan 2003).

CAFi dimensioone on palju uuritud sõltuvate muutujatena, näiteks on vaadeldud, kuidas tööjuhised, õppijate individuaalsed iseärasused, õppekontekst, ülesande sisu jm õppijakeele keerukust, täpsust ja sujuvust mõjutavad (Foster ja Skehan 1996, Norris ja Ortega 2000 ja Yuan ja Ellis 2003). Viimasel ajal uuritakse CAF-triaadi dimensioone palju 
ka kui sõltumatuid muutujaid. Üheks oluliseks uurimissuunaks on seejuures CAFi aluseks olevate kognitiivsete, lingvistiliste ja psühholoogiliste protsesside ning mehhanismide kirjeldamine. Näiteks on Skehan (1998) loonud piiratud tähelepanu mudeli, milles ta väidab, et inimesel on piiratud infotöötlemise võime ja seetõttu ei ole K2 õppijad võimelised kõigile kolmele CAFi dimensioonile korraga võrdsel määral keskenduma. Kui õppijad keskenduvad rohkem keerukusele, võib alaneda täpsus, kui täpsusele, siis võib väheneda sujuvus jne. Robinson (2005) on aga oma tähelepanu mitmekordsete ressursside mudelis tõestanud, et inimese võimed ei ole sugugi nii piiratud. Kokkuvõtteks võib öelda, et keerukus, täpsus ja sujuvus ei arene kindlasti sirgjooneliselt, vaid mõjutavad üksteist mitmesugustel viisidel, kusjuures mõnikord on vastastikune mõju toetav ja mõnikord võistlev (Housen jt 2012).

Eesti keele kui teise keele omandamise uurimisel on senini peamiselt keskendutud vaid täpsuse mõõtmisele ja analüüsile (Maisla 2012, Pool 2007, Pastuhhova 2007, Ratassepp 2007 ja Kitsnik 2006 jpt, vt ka Pool 2010). Viimasel ajal on vähehaaval alustatud ka CAFi teiste dimensioonide uurimist. On ilmunud mõned artiklid õppijakeele keerukust käsitlevate uurimuste kohta (Eslon 2011, 2012 ja Kerge 2009), käimas on uurimus kirjaliku õppijakeele sujuvusest (Pastuhhova 2011).

Käesoleva artikli aluseks võetud uurimuse esimeses osas vaatlesin keerukust verbivormide morfoloogilise jaotuvuse ja sageduse alusel ning uurimuse teises osas verbi tahtma konstruktsioonide morfoloogilise ja süntaktilise jaotuvuse ning sageduse põhjal. Täpsust uurimuse esimeses osas ei ole vaadeldud, teises osas uurisin täpsust konstruktsiooni tasandil, hindasin selle vastavust emakeelekõneleja tavapärasele keelekasutusele vormi ja tähenduse seisukohalt. Sujuvuse mõõtmisega ei ole uurimuses tegeletud.

\section{Uurimismaterjal}

Uurimismaterjal on pärit eesti vahekeele korpusest (edaspidi EVKK), ${ }^{2}$ mille üheks alamkorpuseks on täiskasvanute eesti keele riikliku B1-taseme ja B2-taseme eksami kirjutamisosa tekstid. Eksamisooritused on uurimiseks sobiv materjal, sest 1) nende keeletase on määratud riiklikult tunnustatud hindajate poolt, 2) tekstid pärinevad mitmelt eri eksamilt ja nende hulgas on mitmesse tüüpi kuuluvaid kirjutisi,

2 http://evkk.tlu.ee (29.04.2014) 
mis vähendab ühe tekstitüübi mõju uuritava materjali keeleainesele ja võimaldab seega tulemuste suuremat üldistatavust (vt Norris jt 2002 ja Alanen jt 2010).

Eesti keele kui teise keele oskust mõõdetakse SA Innove korraldatavatel riiklikel tasemeeksamitel A2-, B1-, B2- ja C1-tasemel vastavalt raamdokumendi süsteemile. Eksamil kontrollitakse nelja osaoskust: kuuldu ja loetu mõistmine, kirjutamine ning rääkimine. Iga osaoskuse ülesannete eest võib kokku saada maksimaalselt 25 punkti ja kogu eksami eest 100 punkti. Eksam loetakse sooritatuks, kui eksaminand on kogunud vähemalt $60 \%$ maksimaalsest punktisummast. Uurimismaterjali hulka valisin eksamitööd, mida on eksamil hinnatud 15-23 punktiga (hindamisel arvestatakse ülesande täitmist ja keelekasutust). Alumiseks piiriks määratud 15 punkti on $60 \%$ maksimumist ehk eksami eduka sooritamise piir (eksamil ei pea küll iga osaoskuse eest $60 \%$ punktidest saama, vaid ühe osa madalama tulemuse võib kompenseerida teise osa kõrgemaga). Uurimismaterjali hulka ei ole valitud kõige paremaid sooritusi ( 24 ja 25 punkti saanud töid), arvestades asjaolu, et nende autorite keeleoskustase võib olla ka vastaval eksamil nõutavast kõrgem.

Uurimuse jaoks sobivatest tekstidest koostasin B1-taseme korpuse (kokku 27412 sõnet) ja B2-taseme korpuse (kokku 22128 sõnet). B1-taseme korpuses esinevad järgmised tekstitüübid: teade (umbes 50 sõna), jutt etteantud teemal (umbes 100 sõna), isiklik kiri (umbes 100 sõna). B2-taseme korpuse tekstitüüpideks on poolametlik kiri (umbes 140 sõna), mitteametlik kiri (umbes 140 sõna), arutlus (umbes 180 sõna), lähteandmetele toetuv kokkuvõte koos omapoolse kommentaariga (umbes 180 sõna).

B-tase on käesoleva uurimuse jaoks valitud seetõttu, et see on keeleoskuse arenguprotsessis väga oluline. B-taset nimetatakse iseseisva keelekasutaja tasemeks, selle tasemeni jõudnu suudab iseseisvalt vastavas keeles suhtlemisega hakkama saada. Samas erinevad B1- ja B2-tase teineteisest siiski oluliselt. Kui B1-tasemel tuleb inimene peamiselt toime isiklike asjade korraldamisega, siis B2-tasemel lisandub ühiskondlik tasand: saadakse aru meediast, keerukamast tööalasest keelest, loengutest jmt ning ollakse võimeline töötama juhtivatel ametikohtadel jne.

Küsimusi võib tekitada B1- ja B2-taseme eri tekstitüüpide võrreldavuse objektiivsus. B2-taseme ülesanded on kognitiivselt keerukamad kui B1-taseme omad, samuti erinevad kirjutatavate tekstide tüübid, mis võib hüpoteetiliselt kaasa tuua erinevusi ka tekstides kasutatavates keelestruktuurides. Käesolevas uurimuses olen lähtunud arusaamast, et tekstitüüp on üks keeleoskustaseme omadustest: funktsionaalsetes 
tasemekirjeldustes on määratletud, millise tekstitüübiga antud keeleoskustasemel keelekasutaja toime tuleb (CEFR 2007: 97-105). Uurimused on näidanud, et ainult ülesande keerukus ei too kaasa süntaktiliselt keerukamat ega leksikaalselt varieeruvamat keelekasutust (Kuiken ja Vedder 2012).

Uurimuses ei ole eraldi vaatluse alla võetud tekstiautorite taustainfot (emakeel, haridus, vanus jmt). Taustainfo mittearvestamise üheks põhjuseks on selle info kättesaamatus (eksamikeskusel ei ole õigust seda laadi teavet väljastada). Teisalt ongi uurimuse eesmärgiks kirjeldada tasemepõhist keelekasutust üldiselt, arvestamata eri alarühmadele iseloomulikke jooni. K1-1 on K2-le tõestatult oluline mõju (Jarvis ja Pavlenko 2008, Kaivapalu ja Martin 2007 ja Ringbom 2007), kuid käesolevas uurimuses vaadatakse seda üldistatult, mitte K1-spetsiifiliselt.

\section{Uurimismeetod}

Uurimismeetodina kasutasin korpuse juhitud (ingl corpus-driven) lähenemist ja materjali analüüsil DEMfad-mudelit. Õppijakeelekorpuste uurimine on tänapäeval kiirelt arenemas ${ }^{3}$ ning nende uurimisel kasutatakse kaht peamist lähenemist: korpuspõhine (ingl corpus-based) ja korpuse juhitud (ingl corpus-driven). Korpuspõhise lähenemise korral lähtutakse mingist lingvistilisest teooriast ja otsitakse korpusest materjali sellele teooriale vastavalt. Korpuse juhitud lähenemine on induktiivsem: otsitakse lingvistilisi konstruktsioone, mis korpusest esile kerkivad, ette teadmata, millised need võivad olla (Biber 2009).

Käesolevas uurimuses kasutasin märgendamata korpust ja korpuse poolt juhitud lähenemist, mis vähendab oluliselt uurija eelneva kogemuse ja ootuse mõju tulemustele. Korpuse materjalist moodustasin uurimuse esimeses etapis programmi Simple Concordancer ${ }^{4}$ abil sõnavormide sagedusloendi ja konkordantsid. Seejärel valisin sagedusloendist välja verbivormid sagedusega viis või rohkem, rühmitasin need grammatiliste kategooriate järgi ning leidsin rühmade sagedused kummagi taseme korpuses. Seejärel arvutasin sageduste statistiliselt olulised erinevused B1- ja B2-taseme vahel.

Uurimuse teises etapis võrdlesin verbi tahtma konstruktsioone. Verbi tahtma valisin seetõttu, et see kuulus uurimuse esimeses osas kõrge

3 http://www.learnercorpusassociation.org (29.04.2014)

$4 \mathrm{http}: / /$ softadvice.informer.com/Simple_Concordance_Programme.html (29.04.2014) 
sagedusega tegusõnade hulka ja võib esineda mitmetes erisugustes konstruktsioonides. Verbikonstruktsioonide esinemise kirjeldamisel katsetasin DEMfad-mudeli sobivust B1- ja B2-taseme lingvistilise sisu kirjeldamiseks. Mudel on loodud Jyväskylä ülikooli uurijate (Martin jt 2010) poolt uurimisprojekti Cefling ${ }^{5}$ käigus. Mudeli abil saab mõõta mingi keelenähtuse arengut. Mudel on kujutatud joonisel 1, joonise järel on selgitatud mudeli komponente ja nende kasutamist käesolevas uuringus.

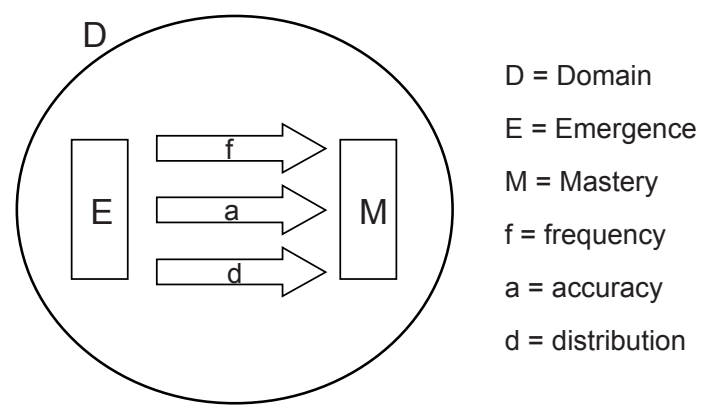

Joonis 1. DEMfad-mudel (Martin jt 2010)

Domeen (ingl domain) on arenev lingvistiline pädevus, mida uuritakse. Domeen ei ole rangelt piiritletud, selleks võib olla mingi käände, konstruktsiooni või sõnarühma kasutamine vm. Samuti ei ole domeeni puhul oluline, mil viisil on õppijad selle nähtuse omandanud, kas produktiivselt (oskavad ise moodustada) või jätnud meelde tervikühikuna konstruktsioonigrammatika põhimõtete järgi (Goldberg 1995, Martin jt 2010 ja Ellis ja Cadierno 2009). Käesoleva artikli aluseks võetud uurimuses on domeenideks verbi tahtma isikulise tegumoe kindla ja tingiva kõneviisi pöördeliste vormide konstruktsioonid, mis kerkisid verbi tahtma puhul korpuse juhitud lähenemisega esile.

Ilmumine (ingl emergence) tähendab uuritava lingvistilise pädevuse ilmumist keelekasutusse. Manfred Pienemanni töödeldavusteooria (ingl processability theory) järgi toimub sõnade, väljendite, vormide ja keelestruktuuride ilmumine õppijakeelde kindlas järjekorras (Pienemann 1998). Ilmumine määratakse DEMfad-mudeli abil eri domeenis erinevate tunnuste järgi. Näiteks määrati Ceflingi uurimuses kohakäänete ilmumine nende morfoloogiliste tunnuste põhjal, transitiivse

5 https://www.jyu.fi/hum/laitokset/kielet/tutkimus/hankkeet/paattyneet-hankkeet/cefling $(29.04 .2014)$ 
konstruktsiooni ilmumist aga teatud kindlas järjendis esineva sõnaderühma järgi (kui nimisõna või asesõna, verb ja teine nimisõna või asesõna asusid lauses üksteise järel sellises järjestuses, et neid võis määrata subjektiks, öeldiseks ja objektiks), ilma käändelõppe arvestamata (Martin jt 2010).

Käesolevas uurimuses määrasin verbivormide ilmumise morfoloogiliste tunnuste järgi, nendega koos esinevate konstruktsioonide ilmumise aga morfoloogiliste tunnuste (näiteks - $d a$ kui infinitiivivormi tunnus), süntaktiliste tunnuste (näiteks et kui kõrvallause tunnus) või sõnaliigi ja sõnajärje alusel (näiteks tahtma pöördeline vorm, millele järgneb teine verb, on loetud infinitiivikonstruktsiooniks). Uurimuses keskendusin domeeni ilmnemisele ja/või esinemisele B1- ja B2 tasemel ega käsitlenud võimalikku varasemat esinemist A1- ja A2-tasemel. Ilmumist vaatlesin keerukuse komponendina (mida rohkem erisuguseid konstruktsioone on ilmunud, seda keerukam tekst on).

Sagedus (ingl frequency) - DEMfad-mudelis kasutatakse sagedust teatud mõttes sujuvuse (ingl fluency) asendajana, sest sujuvust on üldiselt kõige keerukam mõõta, seda nii kirjalikus kui ka suulises tekstis. Et Ceflingi uurimuses kasutati uurimismaterjalina eksamitingimustes ettemääratud ajaga kirjutatud tekste, siis lugesid DEMfad-mudeli autorid sõnade arvu üheks sujuvuse näitajaks. Sageduse mõõtmise eeliseks on nende sõnul ka selle näitaja kõrge objektiivsus. DEMfad-mudelis on sagedus arvutatud 1000 sõne kohta (Martin jt 2010).

Käesolevas uuringus olen verbivormide sagedused esitanud samuti arvutatuna 1000 sõne kohta. Konstruktsioonide sageduse olen esitatud absoluutarvuna. Lisaks olen toonud verbivormide ja -konstruktsioonide sagedusprotsendid teiste sama rühma vormide või konstruktsioonide hulgast ning B1- ja B2-taseme erinevuste olulisuse määramiseks on kasutatud statistilist meetodit $\chi^{2}$-testi. Sagedust ei ole ma vaadanud kui sujuvuse näitajat, sest üldjuhul on eksami sooritamiseks vajaliku arvu punkte saanute tööd sellise pikkusega, mida ülesanne nõuab. Sagedust on käesolevas uurimuses peetud keerukuse näitajaks. Lihtsamate konstruktsioonide suurem sagedus näitab väiksemat keerukust, keerukamate konstruktsioonide suurem sagedus aga suuremat keerukust. Keerukamaks konstruktsiooniks olen seejuures lugenud need, mille struktuur sisaldab rohkem elemente ja/või mille semantika on mitmetähenduslikum (Hawkins 2004).

Täpsus (ingl accuracy) - DEMfad-mudelis võrreldakse täpsuse hindamiseks K2 keelekasutust sama vanuse ja sama haridusega emakeelekõneleja võimaliku keelekasutusega. See tähendab, et mõnikord loetakse 
korrektseks ka mittekirjakeelne vorm, eriti mitteformaalses registris. Täpsuse objektiivsemaks hindamiseks oleks vajalik sobiv emakeelekõnelejate võrdluskorpus, mida Ceflingi uurimuses kasutada polnud. Enamik ebatäpsusi on siiski kergesti määratavad (mittegrammatilised lõpud või kasutused, kirjavead jmt). Vigade liik pole selle mudeli puhul oluline ning iga domeeni jaoks määratakse vea kriteeriumid erinevalt. Kui uuritakse näiteks nimisõnade käänamist, siis on käändelõpu ebakorrektsus viga. Kui aga uuritakse kohakäändeid, siis ei arvestata käändelõpu viga veaks, kuni kääne on äratuntav, veaks arvestatakse vaid vale käände valimine (Martin jt 2010).

Verbi tahtma B1- ja B2-taseme konstruktsioonide uurimuses olen täpsuse määranud uuritava konstruktsiooni ulatuses. Seejuures on täpseks hinnatud kasutusjuhud, mis vastavad emakeelekõneleja tavapärasele keelekasutusele nii struktuuri, semantika kui pragmaatika poolest (Larsen-Freeman 1991), mis on määratud uurija keeletunnetuse alusel.

Jaotuvus (ingl distribution) on konstruktsiooni jagunemine eri alaliikideks. Ceflingi projekti uurimuses kasutati jaotuvust teksti keerukuse määrajana. Konstruktsiooni keerukus võib kasvada mitut moodi: suurenenud leksikaalsete ühikute hulk konstruktsioonis, semantilise või süntaktilise varieeruvuse kasv, konstruktsiooni suurenenud pikkus jm. Jaotuvus on mõiste, mis vajab DEMfadi autorite hinnangul nende mudelis enim edasi arendamist (Martin jt 2010). Käesolevas uurimuses vaatlesin jaotuvust samuti keerukuse komponendina. Võrdlesin verbi tahtma konstruktsioonide jaotuvust nii paradigmaatilisel kui süntagmaatilisel tasandil.

Valdamine (ingl mastery) on uuritava keelepädevuse omandamine. Keelepädevus loetakse DEMfad-mudeli järgi omandatuks, kui seda rakendatakse emakeelekõnelejaile sarnase sageduse ja jaotuvusega ning $80 \%$ korrektsusega. Edaspidi loodetakse võrdlusena kasutada sobivat emakeelekõnelejate võrdluskorpust, mis võimaldab täpsemaid mõõtmisi sageduse ja jaotuvuse osas ning mille tulemuste põhjal saab määrata ka neile künnise (Martin jt 2010).

Käesolevas uurimuses vaatlesin, missugused domeenid on B1- või B2-tasemel omandatud, mis on seal arengujärgus, st õppija ei ole neid omandanud emakeelekõnelejale sarnaselt ning mis ei ole B1-tasemel õppijakeelde veel ilmunud, kuid on ilmunud B2-tasemel (vt ka Salamoura ja Saville 2010). Omandamise kohta pole siiski võimalik veel lõplikku hinnangut anda, selleks oleks vaja võrrelda materjali emakeelekõnelejate võrdluskorpusega. 


\section{Tulemused ja järeldused}

\subsection{Sagedasemad verbivormid B1- ja B2-taseme kirjalikus õppijakeeles}

Uurimuse esimeses osas vaatlesin sagedasemate verbivormide (sama sõna samas vormis, sagedusega viis korda või rohkem) esinemise jaotuvust ja sagedust B1- ja B2-taseme korpuses. Teonimevormid olen nende semantikat arvestades lugenud verbide hulka. Täpsus uurimuse sellel etapil vaatluse all ei olnud.

Tabelites $1-5$ on esitatud kummagi taseme verbivormide sagedused rühmade kaupa (arvutatuna 1000 sõne kohta) ja verbivormide rühmade protsendid kõigist tabelis toodud sama taseme verbivormidest. Tabeli viimases veerus on toodud $\chi^{2}$, mis näitab selle rühma verbivormide B1- ja B2-taseme erinevuse statistilist olulisust. $\chi^{2}$ on arvutatud järgneva valemi järgi: $\chi^{2}=(n-1)(a d-b c)^{2} /(a+b)(a+c)(b+c)(b+d)$, milles $a=$ otsitava vormi sagedus $B 1$ valimis, $b=$ ülejäänud vormide sagedus $B 1$ valimis, $c=$ otsitava vormi sagedus $B 2$ valimis ja $d=$ ülejäänud vormide sagedus B2 valimis. Kui $\chi^{2}$ on suurem kui tabeli all toodud kriitilise piiri väärtus, on tegemist statistiliselt olulise erinevusega (need suurused on tähistatud $*$ ), mida suurem on $\chi^{2}$ väärtus kriitilisest piirist, seda olulisema erinevusega on tegemist. Tabelis 1 on esitatud verbivormide sageduste üldkokkuvõte.

Tabel 1. Verbivormide (sama sõna samas vormis esinemisega 5 korda või rohkem) sagedused B1- ja B2-taseme kirjalikus õppijakeeles

\begin{tabular}{l|c|c|c|c|c} 
Verbivormid & $\begin{array}{c}\text { B1 } \\
\text { (sagedus } \\
\mathbf{1 0 0 0} \\
\text { sone } \\
\text { kohta) }\end{array}$ & $\begin{array}{c}\text { B2 } \\
\text { (sagedus } \\
\mathbf{1 0 0 0} \\
\text { sone } \\
\text { kohta) }\end{array}$ & $\begin{array}{c}\text { B1 } \\
\text { \% tabeli } \\
\text { verbi- } \\
\text { vormi- } \\
\text { dest }\end{array}$ & $\begin{array}{c}\text { B2 } \\
\text { \% tabeli } \\
\text { verbi- } \\
\text { vormi- } \\
\text { dest }\end{array}$ & $\chi^{\mathbf{2}}$ \\
\hline $\begin{array}{l}\text { isikulise tegumoe } \\
\text { kindla kõneviisi } \\
\text { olevikuvormid }\end{array}$ & 65,3 & 103,2 & 43,1 & 62,3 & $287,8^{*}$ \\
\hline $\begin{array}{l}\text { isikulise tegumoe } \\
\text { kindla kõneviisi } \\
\text { lihtminevikuvormid }\end{array}$ & 56,8 & 7,4 & 37,5 & 4,5 & $1236,5^{*}$ \\
\hline $\begin{array}{l}\text { isikulise tegumoe } \\
\text { kindla kõneviisi } \\
\text { täisminevikuvormid }\end{array}$ & 0,3 & 0 & 0,2 & 0 & 7,1 \\
\hline
\end{tabular}




\begin{tabular}{|c|c|c|c|c|c|}
\hline Verbivormid & $\begin{array}{c}\text { B1 } \\
\text { (sagedus } \\
\mathbf{1 0 0 0} \\
\text { sõne } \\
\text { kohta) }\end{array}$ & $\begin{array}{c}\text { B2 } \\
\text { (sagedus } \\
1000 \\
\text { sõne } \\
\text { kohta) }\end{array}$ & $\begin{array}{c}\text { B1 } \\
\% \text { tabeli } \\
\text { verbi- } \\
\text { vormi- } \\
\text { dest }\end{array}$ & $\begin{array}{c}\text { B2 } \\
\% \text { tabeli } \\
\text { verbi- } \\
\text { vormi- } \\
\text { dest }\end{array}$ & $\chi^{2}$ \\
\hline $\begin{array}{l}\text { isikulise tegumoe } \\
\text { tingiva kõneviisi } \\
\text { olevikuvormid }\end{array}$ & 1,8 & 10,5 & 1,2 & 6,3 & $149,0 *$ \\
\hline $\begin{array}{l}\text { umbisikulise tegumoe } \\
\text { kindla kõneviisi } \\
\text { olevikuvormid }\end{array}$ & 0 & 0,4 & 0 & 0,25 & 10,2 \\
\hline $\begin{array}{l}\text { umbisikulise tegumoe } \\
\text { kindla kõneviisi } \\
\text { täisminevikuvormid }\end{array}$ & 0 & 0,3 & 0 & 0,2 & 7,9 \\
\hline $\begin{array}{l}\text { infinitiivivormid ja } \\
\text { des-vorm }\end{array}$ & 26,3 & 40,0 & 17,4 & 24,1 & $54,9 *$ \\
\hline teonimevormid & 1,0 & 3,8 & 0,7 & 2,3 & $37,5^{*}$ \\
\hline
\end{tabular}

Kriitiline piir 14,067

Nagu tabelist 1 ilmneb, on nii B1- kui ka B2-tasemel kõige kõrgem isikulise tegumoe kindla kõneviisi vormide sagedus ( B1-80,8\% ja B2-66,8\% kõigist sama taseme verbivormidest), järgnevad infinitiivivormid + des-vorm (B1-17,4\% ja B2-24,1\%).

Võrreldes vormide esinemissagedusi B1- ja B2-tasemel, on statistiliselt oluline erinevus viie rühma vahel. Kõige suuremad on erinevused kindla kõneviisi lihtminevikuvormide esinemissagedustes (B1-tasemel 37,5\% ja B2-tasemel 4,5\%) ning olevikuvormide esinemissagedustes (B2-tasemel 62,3\% ja B1-tasemel 43,1\%). Vajab edasist uurimist, millest nende vormide esinemissageduse erinevused on tingitud ja kui suurt rolli mängib seejuures tekstitüüp (nimelt on B1-taseme ülesannetes sageli vaja kirjutada oma elus juhtunud sündmustest, mille puhul on lihtmineviku kasutamine üldjuhul vältimatu; B2-taseme ülesanded nõuavad enamasti üldisemat laadi arutlemist, kus lihtmineviku kasutamine pole nii vajalik).

Oluline erinevus on tasemeti ka tingiva kõneviisi vormide sageduses (B2-tasemel on tingiva kõneviisi vorme 6,3\%, B1-tasemel 1,2\%). Ühest küljest võib seda pidada keerukuse kasvuks, sest tingiv kõneviis on morfoloogiliselt keerukam kui kindel kõneviis. Teisest küljest on vaja edasi uurida, kas tegemist on viisaka ja pehmema väljendusviisi oskuse lisandumisega ja kas seda võib pidada ka sujuvuse kasvuks. Ka infinitiivivormide ja des-vormi esinemine erineb statistiliselt olulisel määral 
(B2-tasemel on neid vorme rohkem - 24,1\% B1 taseme 17,4\% vastu). Vajab edasist uurimist, kas see on keerukuse kasvu näitaja (nt millistes konstruktsioonides ja funktsioonides need vormid täpsemalt esinevad). $\mathrm{Ka}$ teonimevormide esinemissagedused $\mathrm{B} 2-2,3 \%$ ja $\mathrm{B} 1-0,7 \%$ on statistiliselt olulise erinevusega.

Järgnevalt on esitatud üksikasjalikum ülevaade vormisagedustest tabelis 1 toodud rühmade sees (kõik verbid on esitatud kokkuvõtlikult verbi tegema vormidena). Tabelis 2 on toodud isikulise tegumoe kindla kõneviisi olevikuvormide esinemissagedused.

Tabel 2. Isikulise tegumoe kindla kõneviisi olevikuvormide sagedused (sama sõna samas vormis esinemisega 5 korda või rohkem) B1- ja B2-taseme kirjalikus õppijakeeles

\begin{tabular}{|c|c|c|c|c|c|}
\hline Verbivormid & $\begin{array}{c}\text { B1 } \\
\text { (sagedus } \\
\text { 1000 sõne } \\
\text { kohta) } \\
\end{array}$ & $\begin{array}{c}\text { B2 } \\
\text { (sagedus } \\
\text { 1000 sõne } \\
\text { kohta) } \\
\end{array}$ & $\begin{array}{c}\text { B1 } \\
\% \text { tabeli } \\
\text { verbivor- } \\
\text { midest }\end{array}$ & $\begin{array}{c}\text { B2 } \\
\text { \% tabeli } \\
\text { verbivor- } \\
\text { midest }\end{array}$ & $\chi^{2}$ \\
\hline teen & 16,1 & 18,5 & 24,7 & 17,9 & $53,0^{*}$ \\
\hline teed & 1,8 & 0,8 & 2,7 & 0,8 & $45,3^{*}$ \\
\hline teeb & 37,2 & 52,0 & 57,0 & 50,4 & $34,0 *$ \\
\hline teeme & 4,1 & 2,5 & 6,3 & 2,4 & $72,7 *$ \\
\hline teete & 1,4 & 0,8 & 2,1 & 0,8 & $25,3 *$ \\
\hline teevad & 1,3 & 18,6 & 2,0 & 18,0 & $505,1^{*}$ \\
\hline ei tee & 3,4 & 10,0 & 5,2 & 9,7 & $54,2 *$ \\
\hline
\end{tabular}

Kriitiline piir 12,592

Nii B1- kui ka B2-tasemel esinevad kõik kindla kõneviisi olevikuvormid. Mõlemal tasemel on kõige sagedasemad ainsuse kolmanda ja ainsuse esimese pöörde vormid. Statistiliselt oluline erinevus on kõigi B1- ja B2-taseme vormide esinemissageduse vahel. Seejuures erinevad enim mitmuse kolmanda pöörde sagedused (B2-18,0\% kõigist sama taseme vormidest ja B1-tasemel 2,0\%). Tabelis 3 on toodud kindla kõneviisi isikulise tegumoe lihtminevikuvormide sagedused. 
Tabel 3. Isikulise tegumoe kindla kõneviisi lihtminevikuvormide sagedused (sama sõna samas vormis esinemisega 5 korda või rohkem) B1- ja B2-taseme kirjalikus õppijakeeles

\begin{tabular}{l|c|c|c|c|c} 
Verbivormid & $\begin{array}{c}\text { B1 } \\
\text { (sagedus } \\
\text { 1000 sõne } \\
\text { kohta) }\end{array}$ & $\begin{array}{c}\text { B2 } \\
\text { (sagedus } \\
\mathbf{1 0 0 0} \text { sõne } \\
\text { kohta) }\end{array}$ & $\begin{array}{c}\text { B1 } \\
\text { \% tabeli } \\
\text { verbivor- } \\
\text { midest }\end{array}$ & $\begin{array}{c}\text { B2 } \\
\text { \% tabeli } \\
\text { verbivor- } \\
\text { midest }\end{array}$ & $\boldsymbol{\chi}^{\mathbf{2}}$ \\
\hline tegin & 20,2 & 2,9 & 35,6 & 39,0 & 3,4 \\
\hline sa (tegid) & 0,2 & 0 & 0,3 & 0 & 2,4 \\
\hline tegi & 25,8 & 3,7 & 45,4 & 50,0 & 5,7 \\
\hline tegime & 8,6 & 0 & 15,2 & 0 & $131,0^{*}$ \\
\hline nad (tegid) & 1,4 & 0,8 & 2,4 & 11,0 & $155,9^{*}$ \\
\hline ei teinud & 0,6 & 0 & 1,0 & 0 & 7,7
\end{tabular}

Kriitiline piir 11,07

B1-tasemel esinevad sagedaste vormide hulgas kõik lihtminevikuvormid peale mitmuse teise pöörde vormi. B2-tasemel esineb sagedaste vormide hulgas vaid kolm lihtminevikuvormi: ainsuse esimese ja kolmanda pöörde vormid ja mitmuse kolmanda pöörde vorm. Statistiliselt olulised erinevused lihtminevikuvormide vahel on ainult mitmuse kolmanda pöörde puhul (B2-tasemel $11 \%$ kõigist sama taseme lihtminevikuvormidest ja B1-tasemel 2,4\%) ning mitmuse esimese pöörde puhul (B1-tasemel 15,2\% kõigist sama taseme lihtminevikuvormidest ja B2-tasemel $0 \%$ ). Tabelis 4 on esitatud isikulise tegumoe tingiva kõneviisi olevikuvormide sagedused.

Tabel 4. Isikulise tegumoe tingiva kõneviisi olevikuvormide sagedused (sama sõna samas vormis esinemisega 5 korda või rohkem) B1- ja B2-taseme kirjalikus õppijakeeles

\begin{tabular}{l|c|c|c|c|c} 
Verbivormid & $\begin{array}{c}\text { B1 (sage- } \\
\text { dus 1000 } \\
\text { sõne } \\
\text { kohta) }\end{array}$ & $\begin{array}{c}\text { B2 (sage- } \\
\text { dus 1000 } \\
\text { sõne } \\
\text { kohta) }\end{array}$ & $\begin{array}{c}\text { B1 \% } \\
\text { tabeli } \\
\text { verbivor- } \\
\text { midest }\end{array}$ & $\begin{array}{c}\text { B2 \% } \\
\text { tabeli } \\
\text { verbivor- } \\
\text { midest }\end{array}$ & $\chi^{\mathbf{2}}$ \\
\hline teeksin & 1,6 & 8,1 & 89,8 & 76,8 & $114,1^{*}$ \\
\hline (sa) teeksid & 0 & 0,3 & 0 & 3,0 & $41,8^{*}$ \\
\hline (ta) teeks & 0,2 & 1,2 & 10,2 & 11,6 & 2,1 \\
\hline teeksime & 0 & 0,9 & 0 & 8,6 & $125,5^{*}$
\end{tabular}

Kriitiline piir 7,815 
Isikulise tegumoe tingiva kõneviisi puhul esineb B1-tasemel kaks vormi ja B2-tasemel neli vormi. Seega suureneb taseme tõustes vormide jaotuvus. Statistiliselt oluline erinevus on mitmuse esimese pöörde vormide vahel (B2-tasemel on neid 8,6\% kõigist vormidest, B1-tasemel 0\%), ainsuse esimese pöörde vormide vahel (B1-tasemel 89,8\% ja B2-tasemel 76,8\%) ning ainsuse teise pöörde vahel (B2-tasemel 3\% ja B1-tasemel $0 \%$ ). Tabelis 5 võib näha infinitiivivormide ja des-vormi sagedusi.

Tabel 5. Infinitiivivormide ja des-vormide sagedused (sama sõna samas vormis esinemisega 5 korda või rohkem) B1- ja B2-taseme kirjalikus õppijakeeles

\begin{tabular}{l|c|c|c|c|c} 
Verbivormid & $\begin{array}{c}\mathbf{B} 1 \\
\text { (sagedus } \\
\mathbf{1 0 0 0} \text { sõne } \\
\text { kohta) }\end{array}$ & $\begin{array}{c}\mathbf{B 2} \\
\mathbf{( s a g e d u s} \\
\mathbf{1 0 0 0} \text { sõne } \\
\text { kohta) }\end{array}$ & $\begin{array}{c}\mathbf{B 1} \% \\
\text { tabeli } \\
\text { verbi- } \\
\text { vormidest }\end{array}$ & $\begin{array}{c}\text { B2 \% } \\
\text { tabeli } \\
\text { verbi- } \\
\text { vormidest }\end{array}$ & \multirow{2}{*}{} \\
\hline teha & 22,3 & 32,9 & 84,7 & 82,3 & $8,6^{*}$ \\
\hline tegema & 3,2 & 5,6 & 12,2 & 14,0 & 5,5 \\
\hline tehes & 0,8 & 1,5 & 3,1 & 3,7 & 2,7
\end{tabular}

Kriitiline piir 5,99

Nagu tabelist näha, kasutatakse nii B1- kui ka B2-tasemel kõige rohkem da-infinitiivi vorme. Seejuures on B1- ja B2-taseme vahel ka oluline statistiline erinevus (B1-tasemel on neid vorme 84,7\% kõigist infinitiivi- ja des-vormidest, B2-tasemel 82,3\%).

\subsection{Verbi tahtma konstruktsioonid B1- ja B2-taseme kirjalikus õppijakeeles}

Uurimuse teises osas vaatlesin verbi tahtma konstruktsioone B1- ja B2-taseme tekstides. Konstruktsioone kirjeldan DEMfad-mudeli abil ning tulemusi analüüsin vastavalt CAF-triaadi dimensioonidele.

Verb tahtma esines nii B1- kui ka B2-tasemel ainult kindla ja tingiva kõneviisi vormides. Samas ei saa uuritava materjali põhjal öelda, millal verbi tahtma kindla kõneviisi ja tingiva kõneviisi vormid esimest korda õppijakeelde on ilmunud, sest see võib olla juhtunud ka juba madalamal tasemel kui B1. Küll aga saab öelda, et teised vormid (nt infinitiivivormid, kesksõnavormid vm) pole verbi tahtma puhul ka B2-tasemel veel keelekasutusse tekkinud. 
Järgnevalt vaatlen verbi tahtma kindla kõneviisi konstruktsioonide (osas 5.2.1) ning tingiva kõneviisi konstruktsioonide (osas 5.2.2) esinemist B1- ja B2-taseme õppijakeeles.

\subsubsection{Verbi tahtma kindla kõneviisi konstruktsioonid}

Kokku esineb verbi tahtma isikulise tegumoe kindla kõneviisi vorme B1-tasemel 147 korda (5,4 korda 1000 sõne kohta ja 76,6\% kõigist tahtma vormidest samal tasemel) ja B2-tasemel 85 korda (3,8 korda 1000 sõne kohta ja 50\% kõigist tahtma vormidest samal tasemel). Kindla kõneviisi vormide vahel on statistiliselt oluline erinevus (kriitiline piir 3,841 ja $\chi^{2}=596,82$ ). Seega langeb keeleoskuse arenedes verbi tahtma isikulise tegumoe kindla kõneviisi olevikuvormide sagedus olulisel määral. Tabelis 6 on esitatud kokkuvõte konstruktsioonidest tahtma kindlas kõneviisis + VERBinf B1- ja B2-tasemel. Esinemissagedused on esitatud absoluutarvudena. Arv enne sulge näitab kõigi vastava rühma konstruktsioonide sagedust, arv sulgudes näitab vastava rühma korrektsete konstruktsioonide sagedust ja $\chi^{2}$ on arvutatud kõigi konstruktsioonide esinemissageduste põhjal.

Tabel 6. Verbi tahtma isikulise tegumoe kindla kõneviisi konstruktsioonid verbi infinitiivivormiga B1- ja B2-taseme kirjalikus õppijakeeles

\begin{tabular}{l|c|c|c|c|c}
$\begin{array}{l}\text { Verbi- } \\
\text { konstruktsioonid }\end{array}$ & $\begin{array}{c}\text { B1 } \\
\text { sagedus } \\
\text { (absoluut- } \\
\text { arvud) }\end{array}$ & $\begin{array}{c}\text { B2 } \\
\text { sagedus } \\
\text { absoluut- } \\
\text { arvud) }\end{array}$ & $\begin{array}{c}\text { B1 } \\
\text { \% tabeli } \\
\text { konstrukt- } \\
\text { sioonidest }\end{array}$ & $\begin{array}{c}\text { B2 } \\
\text { \% tabeli } \\
\text { konstrukt- } \\
\text { sioonidest }\end{array}$ & $\boldsymbol{\chi}^{\mathbf{2}}$ \\
\hline tahan + VERB inf & $93(86)$ & $35(35)$ & 67,4 & 48,6 & $261,0^{*}$ \\
\hline tahad + VERB inf & $14(14)$ & $4(4)$ & 10,1 & 5,6 & $47,3^{*}$ \\
\hline tahab + VERB inf & $7(5)$ & $9(8)$ & 5,1 & 12,5 & $138,0^{*}$ \\
\hline tahame + VERB inf & $0(0)$ & $5(5)$ & 0 & 7,0 & $365,4^{*}$ \\
\hline tahate + VERB inf & $5(3)$ & $0(0)$ & 3,6 & 0 & $99,5^{*}$ \\
\hline tahavad + VERB inf & $0(0)$ & $12(12)$ & 0 & 16,7 & $908,0^{*}$ \\
\hline ei taha + VERB inf & $1(1)$ & $7(7)$ & 0,7 & 9,7 & $389,1^{*}$ \\
\hline tahtsin + VERB inf & $18(15)$ & $0(0)$ & 13,0 & 0 & $382,3^{*}$
\end{tabular}

Kriitiline piir 14,07 
Tabelis 7 on esitatud kokkuvõte verbi tahtma isikulise tegumoe kindla kõneviisi vormide ülejäänud konstruktsioonidest. Esinemissagedused on esitatud absoluutarvudena. Arv enne sulge näitab kõigi vastava rühma konstruktsioonide sagedust, arv sulgudes aga näitab vastava rühma korrektsete konstruktsioonide sagedust. Et selles tabelis esitatud konstruktsioonide sagedus on väga väike, pole $\chi^{2}$ arvutatud. Tabelite järel on kirjeldatud konstruktsioonide jaotuvust, sagedust ja täpsust.

Tabel 7. Verbi tahtma isikulise tegumoe kindla kõneviisi ülejäänud konstruktsioonid B1- ja B2-taseme kirjalikus õppijakeeles

\begin{tabular}{|c|c|c|c|c|c|c|}
\hline $\begin{array}{l}\text { PÕHI- } \\
\text { SÕNA }\end{array}$ & $\begin{array}{c}\text { B1 + } \\
\text { KÕRVAL- } \\
\text { LAUSE } \\
\text { sagedus } \\
\text { (absoluut- } \\
\text { arvud) }\end{array}$ & $\begin{array}{c}\text { B2 + } \\
\text { KÕRVAL- } \\
\text { LAUSE } \\
\text { sagedus } \\
\text { (absoluut- } \\
\text { arvud) }\end{array}$ & $\begin{array}{c}\text { B1 + Ø } \\
\text { sagedus } \\
\text { (abso- } \\
\text { luut- } \\
\text { arvud) }\end{array}$ & $\begin{array}{c}\text { B2 + Ø } \\
\text { sagedus } \\
\text { (abso- } \\
\text { luut- } \\
\text { arvud) }\end{array}$ & \begin{tabular}{|c|} 
B1 + \\
NOO- \\
MEN \\
sagedus \\
(absoluut- \\
arvud) \\
\end{tabular} & \begin{tabular}{|c} 
B2 + \\
NOO- \\
MEN \\
sagedus \\
(absoluut- \\
arvud) \\
\end{tabular} \\
\hline tahan & $2(1)$ & $4(2)$ & $2(2)$ & $1(1)$ & & \\
\hline tahad & & & & & & $2(2)$ \\
\hline tahab & & & $3(2)$ & $2(2)$ & $1(0)$ & \\
\hline tahame & & $1(1)$ & & & & \\
\hline tahate & & & & & $1(0)$ & \\
\hline tahavad & & $1(0)$ & & $2(2)$ & & \\
\hline
\end{tabular}

\section{Konstruktsioonide jaotuvus}

Tabelitest 6 ja 7 ilmneb, et nii B1- kui ka B2-tasemel esineb verb tahtma kuues vormis. Mõlemal tasemel esinevad vormid tahan, tahad, tahab ja ei taha. Erinevusena esinevad ainult B1-tasemel vorm tahate ning lihtmineviku vorm tahtsin, ainult B2-tasemel on olemas vormid tahame ja tahavad. Süntagmaatiliselt esineb kummalgi tasemel neli konstruktsiooni: 1) tahtma pöördeline vorm + infinitiivivorm, 2) tahtma pöördeline vorm + kõrvallause, 3) tahtma pöördeline vorm + noomen ja 4) tahtma pöördeline vorm $+\varnothing$.

\section{Konstruktsioonide sagedus}

Konstruktsioonide hulgas domineerib tahtma pöördeline vorm + infinitiivivorm: B1-tasemel esineb seda 94\% kõigist juhtudest ja B2-tasemel $85 \%$. Seega on domineeriva konstruktsiooni sagedus kõrgemale keeleoskuse tasemele arenedes veidi vähenenud. Ülejäänud kolme konstruktsiooni esineb kummalgi tasemel vähe. 


\section{Konstruktsioonide täpsus}

Konstruktsioonide üldine täpsus on mõlemal tasemel kõrge B1-tasemel on $88 \%$ ja B2-tasemel 95\% konstruktsioonidest korrektsed. Seega kasvab konstruktsioonide täpsus kõrgemale tasemele liikudes 7\%.

Järgnevalt on lähemalt vaadeldud domineerivat konstruktsiooni tahtma pöördeline vorm + infinitiivivorm ja konstruktsiooni tahtma pöördeline vorm + kõrvallause, mille puhul pakub huvi eelkõige tema kasutustäpsus.

\section{Konstruktsioon tahtma pöördeline vorm + infinitiivivorm}

Konstruktsioon tahtma pöördeline vorm + infinitiivivorm esineb küll nii B1- kui ka B2-tasemel kuue verbivormiga, kuid domineeriv on mõlemal tasemel suure ülekaaluga konstruktsioon ainsuse esimese pöörde vorm tahan + infinitiivivorm - B1-tasemel esineb seda $67 \%$ konstruktsioonide üldarvust ja B2-tasemel 49\%. Seega väheneb keeleoskuse arenedes selle konstruktsiooni domineerivus. Kõigi pöördevormidega konstruktsioonide esinemissagedustes on B1- ja B2-tasemel statistiliselt olulised erinevused. Järgnevalt on esitatud tüüpiliste kasutusjuhtude näiteid kummaltki tasemelt.

(B1) Minu töökaaslased! Tahan Teile teatada, et ma ...

(B1) ... mul on üks pilet on vaba. Ma tahan pakkuda sulle see pilet.

(B2) Lepingu tahan sõlmida pikaks ajaks, ...

(B2) Kokkuvõttes, ma tahan öelda, et minu arvates ...

Konstruktsiooni täpsus on B1-tasemel kõrge - 90\% ja B2-tasemel ülikõrge - 99\%. Seega kasvab sagedase konstruktsiooni täpsus keeleoskuse arenedes. B1-taseme ebatäpsused on seotud vale sõnakasutuse, vale infinitiivi valiku, vale pöördelõpu ja vale ajakasutusega.

\section{Konstruktsioon tahtma pöördeline vorm + kõrvallause}

Konstruktsiooni sagedus kummalgi tasemel on väga madal. B1-tasemel on esinemisnäiteid kaks ja B2-tasemel kuus. Kõik konstruktsioonid sisaldavad sidesõna et, millele järgneb kõrvallause. B1-tasemel on üks esinemisjuht täpne ja teine mitte ning B2-tasemel on kolm esinemisjuhtu täpsed ja kolm mitte. Alljärgnevalt on esitatud tüüpiline täpne ja tüüpiline ebatäpne kasutusjuht B2-tasemel.

(B2) ... aga me tahame et korteris oleks soe.

(B2) Praegu tahan, et meie leping kestis ...* 
Tüüpiline ebatäpsus on seotud kõrvallause kõneviisi valikuga: vajaliku tingiva kõneviisi asemel on kasutatud kindla kõneviisi lihtminevikuvormi.

\subsubsection{Verbi tahtma tingiva kõneviisi konstruktsioonid}

Kokku esineb verbi tahtma tingiva kõneviisi vorme B1-tasemel 45 korda (ehk 1,6 korda 1000 sõne kohta ja 23,4\% kõigist tahtma vormidest samal tasemel) ning B2-tasemel 85 korda (3,8 korda 1000 sõne kohta ja 50\% kõigist tahtma vormidest samal tasemel). Tingiva kõneviisi vormide vahel on statistiliselt oluline erinevus (kriitiline piir 3,841 ja $\chi^{2}=596,82$ ). Seega tõuseb keeleoskuse arenedes verbi tahtma tingiva kõneviisi olevikuvormide sagedus oluliselt. Silma torkab ka asjaolu, et B1-tasemel esineb tingiva kõneviisi vorme tunduvalt vähem kui kindla kõneviisi vorme samal tasemel, B2-tasemel on aga kindla ja tingiva kõneviisi vormide esinemissagedused võrdsed.

Tabelis 8 on esitatud kokkuvõte konstruktsioonidest tahtma tingivas kõneviisis + VERBinf B1-ja B2-tasemel. Esinemissagedused on esitatud absoluutarvudena. Arv enne sulge näitab kõigi vastava rühma konstruktsioonide sagedust, arv sulgudes näitab vastava rühma korrektsete konstruktsioonide sagedust ja $\chi^{2}$ on arvutatud kõigi konstruktsioonide esinemissageduste põhjal.

Tabel 8. Verbi tahtma tingiva kõneviisi konstruktsioonid verbi infinitiivivormiga B1- ja B2-taseme kirjalikus õppijakeeles

\begin{tabular}{l|c|c|c|c|c} 
Verbivormid & $\begin{array}{c}\text { B1 } \\
\text { sagedus } \\
\text { (abso- } \\
\text { luut- } \\
\text { arvud) }\end{array}$ & $\begin{array}{c}\text { B2 } \\
\text { sagedus } \\
\text { (abso- } \\
\text { luut- } \\
\text { arvud) }\end{array}$ & $\begin{array}{c}\text { B1 \% } \\
\text { tabeli } \\
\text { kon- } \\
\text { strukt- } \\
\text { sioonidest }\end{array}$ & $\begin{array}{c}\text { B2 \% } \\
\text { tabeli } \\
\text { kon- } \\
\text { strukt- } \\
\text { sioonidest }\end{array}$ & \multirow{2}{\chi^{2}}{} \\
\hline tahaksin + VERB inf & $30(15)$ & $56(55)$ & 75,0 & 70,9 & $14,7 *$ \\
\hline (ma/sa) tahaks + VERB inf & $10(6)$ & $10(9)$ & 25,0 & 12,7 & $190,0^{*}$ \\
\hline tahaksime + VERB inf & 0 & $13(10)$ & 0 & 16,5 & $485,3^{*}$
\end{tabular}

Kriitiline piir 5,99

Tabelis 9 on esitatud kokkuvõte verbi tahtma isikulise tegumoe tingiva kõneviisi vormide ülejäänud konstruktsioonidest. Esinemissagedused on esitatud absoluutarvudena. Arv enne sulge näitab kõigi vastava rühma konstruktsioonide sagedust, arv sulgudes aga näitab 
vastava rühma korrektsete konstruktsioonide sagedust. Et selles tabelis esitatud konstruktsioonide sagedus on väga väike, pole $\chi^{2}$ arvutatud. Tabelite järel on kirjeldatud konstruktsioonide jaotuvust, sagedust ja täpsust.

Tabel 9. Verbi tahtma isikulise tegumoe kindla kõneviisi ülejäänud konstruktsioonid B1- ja B2-taseme kirjalikus õppijakeeles

\begin{tabular}{|c|c|c|c|c|c|c|}
\hline $\begin{array}{l}\text { PÕHI- } \\
\text { SÕNA }\end{array}$ & \begin{tabular}{|c|} 
B1 + \\
KÕVAL- \\
LAUSE \\
sagedus \\
(abso- \\
luut- \\
arvud)
\end{tabular} & \begin{tabular}{|c|} 
B2 + \\
KÕVAL- \\
LAUSE \\
sagedus \\
(abso- \\
luut- \\
arvud)
\end{tabular} & $\begin{array}{c}\text { B1 + Ø } \\
\text { sagedus } \\
\text { (abso- } \\
\text { luut- } \\
\text { arvud) }\end{array}$ & $\begin{array}{c}\text { B2 + Ø } \\
\text { sagedus } \\
\text { (abso- } \\
\text { luut- } \\
\text { arvud) }\end{array}$ & $\begin{array}{c}\text { B1 + } \\
\text { NOO- } \\
\text { MEN } \\
\text { sagedus } \\
\text { (abso- } \\
\text { luut- } \\
\text { arvud) }\end{array}$ & $\begin{array}{c}\text { B2 + } \\
\text { NOO- } \\
\text { MEN } \\
\text { sagedus } \\
\text { (abso- } \\
\text { luut- } \\
\text { arvud) }\end{array}$ \\
\hline tahaksin & $3(0)$ & & $1(1)$ & & $1(0)$ & $1(1)$ \\
\hline $\begin{array}{l}\text { (ma/sa) } \\
\text { tahaks }\end{array}$ & & $2(0)$ & & & & \\
\hline tahaksime & & $1(0)$ & & & & $2(1)$ \\
\hline
\end{tabular}

\section{Konstruktsioonide jaotuvus}

Nagu tabelitest 8 ja 9 näha, esineb verb tahtma B1-tasemel kahes vormis ja B2-tasemel kolmes vormis. Mõlemal tasemel esinevad vormid tahaksin ja tahaks, millele B2-tasemel lisandub tahaksime. Süntagmaatiliselt esineb B1-tasemel neli konstruktsiooni ja B2-tasemel kolm. Mõlemal tasemel esinevad konstruktsioonid: 1) tahtma pöördeline vorm + infinitiivivorm, 2) tahtma pöördeline vorm + kõrvallause, 3) tahtma pöördeline vorm + noomen. Ainult B1-tasemel esineb üks kord ka konstruktsioon tahtma pöördeline vorm $+\varnothing$.

\section{Konstruktsioonide sagedus}

Nagu kindla kõneviisi konstruktsioonide puhul, domineerib ka tingivas kõneviisis konstruktsioon tahtma pöördeline vorm + infinitiivivorm: B1-tasemel esineb seda $89 \%$ kõigist juhtudest ja B2-tasemel $93 \%$. Ülejäänud kolme konstruktsiooni esineb kummalgi tasemel vähe nagu kindla kõneviisigi puhul.

\section{Konstruktsioonide täpsus}

Tingiva kõneviisi konstruktsioonide üldine täpsus B1-tasemel on $49 \%$ ja B2-tasemel $89 \%$. Seega kasvab verbi tahtma tingiva kõneviisi konstruktsioonide täpsus keeleoskuse arenedes märgatavalt. 
Järgnevalt on lähemalt vaadeldud domineerivat konstruktsiooni tahtma pöördeline vorm + infinitiivivorm ja konstruktsiooni tahtma pöördeline vorm + kõrvallause, mille puhul pakub huvi eelkõige tema kasutustäpsus.

\section{Konstruktsioon tahtma pöördeline vorm + infinitiivivorm}

Konstruktsiooni tahtma pöördeline vorm + infinitiivivorm puhul domineerivad nagu kindlas kõneviisiski ainsuse esimese pöörde vormid - B1-tasemel esineb $75 \%$ juhtudest tingiva kõneviisi pikk vorm tahaksin. 25\% juhtudest esineb lühivorm tahaks (ainsuse esimese ja teise pöörde vormis). B2-tasemel esineb ainsuse esimese pöörde vorme $71 \%$ juhtudest, lühivorm tahaks (ainsuse esimese ja teise pöörde vormis) esineb $13 \%$ juhtudest. Lisaks esineb mitmuse esimese pöörde vormi tahaksime $16 \%$ juhtudest. Järgnevalt on esitatud tüüpiliste kasutusjuhtude näiteid kummaltki tasemelt.

(B1) ... kallis kolleega Valentina! Ma tahaksin sind kutsuda ...

(B1) Tere Tanja! Tahaks sind kontsertil kutsuda.

(B2) Kokkuvõtteks, tahaksin öelda, et igal juhul ...

Konstruktsiooni täpsus on B1-tasemel 53\% ja B2-tasemel 94\%. Seega kasvab konstruktsiooni täpsus keeleoskuse arenedes märgatavalt. Järgnevalt on esitatud tüüpilise ebatäpse kasutusjuhu näide.

(B1) Lapsena ma tahaksin saada politseinikuna*

Tüüpiline eksimus on selle konstruktsiooni puhul tingiva kõneviisi olevikuvormi kasutamine kindla kõneviisi lihtminevikuvormi asemel. Vajab edasist uurimist, kas tegemist on tüüpveaga vaid sõna tahtma kasutuses.

\section{Konstruktsioon tahtma pöördeline vorm + kõrvallause}

Seda konstruktsiooni esineb kummalgi tasemel kolm korda. Kõik juhud sisaldavad sidesõna et, millele järgneb kõrvallause. Seejuures on kõik kasutusjuhud ebatäpsed. Järgnevalt on esitatud tüüpilised ebatäpsete kasutusjuhtude näited.

(B1) ... see laulja, ja ma väga tahaksin, et sa koos minuga kontserdile minna.* 
(B2) ... magustoidud ja küpsetised? Tahaksime väga et teie kirjutasite vastused.*

Seda tüüpi lausetes peab kõrvallause öeldis olema tingivas kõneviisis. Selle asemel on aga kasutatud lihtmineviku- või infinitiivivormi.

\section{Kokkuvõte}

Uurimuse esimese osa kokkuvõtteks võib öelda, et nii B1- kui ka B2-tasemel esinevad sagedasemad verbivormid küllalt piiratud kujul: peamiselt isikulise tegumoe kindla kõneviisi olevikus ja lihtminevikus, tingiva kõneviisi olevikus ning infinitiividena. B1-tasemel esineb oluliselt rohkem kindla kõneviisi lihtminevikuvorme ning B2-tasemel kindla kõneviisi olevikuvorme (sh rohkem mitmuse kolmanda pöörde vorme). Vajab edasist uurimist, mil määral on olevikuvormide domineerimine B2-tasemel ja lihtminevikuvormide kõrgem esinemissagedus B1-tasemel tingitud tekstitüübist ning mil määral muudest põhjustest. B2-tasemel suureneb oluliselt tingiva kõneviisi vormide sagedus ja ka jaotuvus (kaks pöördevormi B1-tasemel ja neli B2-tasemel). Seda võib pidada keerukuse kasvuks, sest tingiv kõneviis on morfoloogiliselt keerukam kui kindel kõneviis. Samuti suureneb B2-tasemel infinitiivivormide sagedus. Edaspidi oleks vajalik vaadata ka väiksema korduvusega vormide (nt täismineviku ja umbisikulise tegumoe vormid) esinemist kõigi, mitte ainult viie või enama sagedusega verbivormide hulgas. Seda ongi plaanis uuringu järgmisel etapil teha.

Seejärel on vaja uurida lähemalt tasemete erinevusi CAF-triaadi dimensioonide (keerukus, korrektsus, sujuvus) põhjal. Tuleks vaadelda tingiva kõneviisi vormide funktsioonide jaotuvust (nt uurida, kas tingiva kõneviisi sagedasem kasutamine on tingitud viisakama ja pehmema väljendusviisi omandamisest ja kas seda võiks pidada sel juhul ka sujuvuse kasvuks). Keerukuse ja sujuvuse uurimiseks oleks seejuures väga kasulik ka võrdlus emakeelekõnelejate tekstidega.

Uurimuse teise osa kokkuvõtteks võib öelda, et nii B1- kui ka B2-tasemel esineb verb tahtma isikulise tegumoe kindla kõneviisi ja tingiva kõneviisi vormides ning mõlemal tasemel eelistatakse ainsuse esimese pöörde vorme. Samuti kasutatakse mõlemal tasemel valdavalt üht tüüpi konstruktsiooni - verbi tahtma pöördeline vorm (kindlas või tingivas kõneviisi) + infinitiivivorm. Taseme tõustes konstruktsioonide täpsus kasvab. Veel esinevad kummalgi tasemel konstruktsioonid verbi 
tahtma pöördeline vorm + kõrvallause, verbi tahtma pöördeline vorm + noomen ja verbi tahtma pöördeline vorm $+\varnothing$. Nende konstruktsioonide sagedus on mõlemal tasemel väga madal ja konstruktsioonide täpsus ei ole kõrge.

Tasemete ühe olulise erinevusena võib esile tuua kindla kõneviisi vormide sageduse tunduva vähenemise ja tingiva kõneviisi vormide sageduse tunduva kasvu seoses keeleoskuse tõusuga. Seega muutub keelekasutus selles osas B2-tasemel keerukamaks, kui oli B1-tasemel. Vajab edasist uurimist, milline on konstruktsioonide funktsionaalne jaotuvus ja kas see kasvab keeleoskustaseme tõustes. Nii saaks vaadelda, kas tingiva kõneviisi kasutamissageduse kasv taseme tõustes näitab viisakama ja pehmema väljendusviisi kasutusoskuse tõusu ja kas seda võiks pidada ka sujuvuse kasvuks. Teine silmapaistev erinevus tasemete vahel on tingiva kõneviisi vormide täpsuse kasv keeleoskustaseme tõustes. Edaspidi on vaja uurida, kas selline täpsuse kasv on seotud verbiga tahtma või üldisem.

\title{
Tänuavaldus
}

Tänan Erika Matsakit ja Keaty Siiveltit nõu ja abi eest statistilise analüüsi teostamisel.

\author{
Aadress: \\ Mare Kitsnik \\ Eesti keele ja kultuuri instituut \\ Tallinna Ülikool \\ Narva mnt 25 \\ 10120 Tallinn, Eesti \\ E-mail: marekitsnik@gmail.com
}

\section{Kirjandus}

Alanen, Riikka, Ari Huhta ja Mirja Tarnanen (2010) „Designing and assessing L2 writing tasks acrossing CEFR proficiency levels”. Teoses Inge Bartning, Maisa Martin ja Ineke Vedder, toim. Communicative proficiency and linguistic development: intersections between SLA and language testing research, 21-56 (Eurosla Monographs Series, 1.) Kättesaadav aadressil <http://eurosla.org/monographs/ EM01/EM01home.html>. Vaadatud 01.05.2014.

Bachman, Lyle ja Adrian Palmer (2010) Language assessment in practice. Oxford: Oxford University Press. 
Biber, Douglas (2009) „Corpus-based and corpus-driven analyses of language variation and use". Teoses Bernd Heine ja Heiko Narrog, toim. The Oxford handbook of linguistic analyses, 159-192. Oxford: Oxford University Press.

Bulté, Bram ja Alex Housen (2012) „Defining and operationalising L2 complexity”. Teoses Alex Housen, Folkert Kuiken ja Ineke Vedder, toim. Dimensions of L2 performance and proficiency. Complexity, accuracy and fluency in SLA, 21-46. Amsterdam/Philadelphia: Benjamins.

Ellis, Rod (2008) The study of second language acquisition. Oxford: Oxford University Press.

Ellis, Nick C. ja Teresa Cadierno (2009) „Construction a second language”. Introduction to a special section. Annual Review of Cognitive Linguistics 7, 111-139.

Eslon, Pille (2011) „Millest räägivad eesti keele käändeasendused?” Lähivõrdlusi. Lähivertailuja 21, 45-64.

Eslon, Pille (2012) „Objekti ja tegevuse markeeritus eesti õppijakeeles”. Lähivõrdlusi. Lähivertailuja 22, 15-42.

Foster, Pauline ja Peter Skehan (1996) „The influence of planning on performance in task-based learning”. Studies in Second Language Acquisition 18, 3, $299-324$.

Goldberg, Adele (1995) Constructions. A construction grammar approach to argument structure. Cognitive theory of language and culture. Chicago IL: The University of Chicago Press.

Gunnarsson, Cecilia (2012) „The development of complexity, accuracy and fluency in the written production of L2 French". Teoses Alex Housen, Folkert Kuiken ja Ineke Vedder, toim. Dimensions of L2 performance and proficiency. Complexity, accuracy and fluency in SLA, 247-276. Amsterdam/Philadelphia: Benjamins.

Hausenberg, Anu-Reet, Marju Ilves, Annekatrin Kaivapalu, Krista Kerge, Katrin Kern, Mare Kitsnik, Ingrid Krall, Karin Rummo ja Tiina Rüütmaa (2008) Iseseisev keelekasutaja. B1-ja B2-taseme eesti keele oskus. Tallinn: REKK, Atlex.

Hawkins, John A. (2004) Efficiency and complexity in grammars. Oxford: Oxford University Press.

Housen, Alex, Folkert Kuiken ja Ineke Vedder (2012) „Complexity, accuracy and fluency. Definitions, measurement and research”. Teoses Alex Housen, Folkert Kuiken, Ineke Vedder, toim. Dimensions of L2 performance and proficiency. Complexity, accuracy and fluency in SLA, 1-20. Amsterdam/Philadelphia: Benjamins.

Housen, Alex ja Folkert Kuiken (2009) „Complexity, accuracy and fluency in second language acquisition”. Applied Linguistics 30, 4, 461-473.

Hulstijn, Jan H., J. Charles Alderson ja Rob Schoonen (2010) „Developmental stages in second-language acquisition and levels of second-language proficiency. Are there links between them?" Teoses Inge Bartning, Maisa Martin ja Ineke Vedder, toim. Communicative proficiency and linguistic development: intersections between SLA and language testing research, 11-20. (Eurosla Monographs Series, 1.) Kättesaadav aadressil $<$ http://eurosla.org/monographs/EM01/EM01home.html>. Vaadatud 01.05.2014.

Hulstijn, Jan H. ja Rick de Graaff (1994) „Under what conditions does explicit knowledge of a second language facilitate the acquisition of implicit knowledge?" A research proposal. Aila Review 11, 97-112. 
Ilves, Marju (2008) Algaja keelekasutaja. A2-taseme eesti keele oskus. Tallinn: EKSA. Ilves, Marju (2010) Läbimurre. Al-taseme eesti keele oskus. Tallinn: EKSA.

Jarvis, Scott (2013) „Defining and measuring lexical diversity”. Teoses Scott Jarvis ja Michael Daller, toim. Vocabulary knowledge. Human ratings and automated measures, 13-44. Amsterdam/Philadelphia: Benjamins.

Jarvis, Scott ja Aneta Pavlenko (2008) Crosslinguistic influence in language and cognition. New York: Routledge.

Kaivapalu, Annekatrin ja Maisa Martin (2007) „Morphology in transition: plural inflection of Estonian nouns by Estonian and Russian learners". Acta Linguistica Hungarica 54, 2, 129-156.

Kerge, Krista (2008) Vilunud keelekasutaja. C1-taseme eesti keele oskus. Tallinn: EKSA.

Kitsnik, Mare (2007) „Eesti keele kui teise keele õppija kõrvalekalded eituse väljendamisel”. Tallinna ülikooli eesti filoloogia osakonna toimetised 9, 152-181.

Kitsnik, Mare (2011) „Keelestruktuuride õpetamine seostatult keeletasemete, teemade ja osaoskustega". Teoses Piret Kanne, Annelii Juhkama, Reet Taimsoo, Katrin Meinart, Ülle Türk, Tuuli Oder, Merle Jung ja Pille Eslon, toim. Gümnaasiumi valdkonnaraamat. Tallinn: REKK. Kättesaadav aadressil < http://www.oppekava.ee/images $/ 5 / 57 /$ Keelestruktuuride_\%C3\%B5petamine_seoses_teemade_ja_osaoskustega. pdf $>$._Vaadatud 01.05.2014.

Kuiken, Volkert ja Ineke Vedder (2012) „Syntactic complexity, lexical variation and accuracy as a function of task complexity and proficiency level in L2 writing and speaking". Teoses Alex Housen, Folkert Kuiken ja Ineke Vedder, toim. Dimensions of L2 performance and proficiency. Complexity, accuracy and fluency in SLA, 143170. Amsterdam/Philadelphia: Benjamins.

Larsen-Freeman, Diane (1991) „Teaching grammar”. Teoses Marianne Celce-Murcia, toim. Teaching English as a second or foreign language, 279-283. Boston, MA: Heinle ja Heinle.

Larsen-Freeman, Diane (2006) „The emergence of complexity, fluency and accuracy in the oral and written production of five Chinese learners of English". Applied Linguistics 27, 4, 590-619.

Larsen-Freeman, Diane (2009) „Adjusting expectations: The study of complexity, accuracy and fluency in second language acquisition". Applied Linguistics 30, 4, 579-589.

Maisla, Diana (2012) „Eesti mineviku liitvormide kasutamisest õppijakeele korpuse materjali põhjal”. Eesti ja soome-ugri keeleteaduse ajakiri ESUKA-JEFUL 3, 2, $129-152$.

Martin, Maisa, Sanna Mustonen, Niina Reiman ja Marja Seilonen (2010) „On becoming an independent user”. Teoses Inge Bartning, Maisa Martin ja InekeVedder, toim. Communicative proficiency and linguistic development: intersections between SLA and language testing research, 57-80. (Eurosla Monographs Series, 1.) Kättesaadav aadressil <http://eurosla.org/monographs/EM01/EM01home.html>. Vaadatud 01.05.2014. 
Norris John M. ja Lourdes Ortega (2000) „Effectiveness of L2 instruction: A research synthesis and quantitative meta-analysis". Language Learning 50, 3, 417-528.

Norris John M. ja Lourdes Ortega (2009) „Towards an organic approach to investigating CAF in instructed SLA: The case of complexity". Applied Linguistics 30, 4, $555-578$.

Norris, John M., James D. Brown, Thom D. Hudson ja William Bonk (2002) „Examinee abilities and task difficulty in task baced second language assesment”. Language Testing 19, 337-346.

Pajupuu, Hille, Krista Kerge ja Pilvi Alp (2009), „Sõnavara loomulik rikkus haritud keelekasutaja tekstides". Eesti Rakenduslingvistika Ühingu aastaraamat 5, 187-196.

Pallotti, Gabriele (2009) „CAF: Defining, refining and differentiating constructs”. Applied Linguistics 30, 4, 590-601.

Paquot, Magali ja Sylviana Granger (2012) „Formulaic language in learner corpora”. Annual Review of Applied Linguistics 32, 130-149.

Pastuhhova, Olga (2005) „Interferentsivead vene üliõpilaste suulise ja kirjaliku eesti keele süntaksis”. Teoses Raili Pool, toim. Teine keel, 75-110. (Tartu Ülikooli eesti keele (võõrkeelena) õppetooli toimetised, 5.) Tartu: Tartu Ülikooli Kirjastus.

Pastuhhova, Olga (2011) „Kirjaliku produtseerimisprotsessi uurimise võimalused programmi ScriptLog abil: Juhtumiuuring”. Lähivõrdlusi. Lähivertailuja 21, 185-212.

Pienemann, Manfred (1998) Language processing and second language development. Processability theory. Amsterdam: Benjamins.

Pool, Raili (2007) Eesti keele teise keelena omandamise seaduspärasusi täis- ja osasihitise näitel. (Dissertationes philologicae estonicae universitatis Tartuensis, 19.) Tartu: Tartu Ülikooli Kirjastus.

Pool, Raili (2010) „Eesti keele teise keelena uurimine Tartu ülikoolis - hetkeseis ja perspektiivid." Eesti ja soome-ugri keeleteaduse ajakiri ESUKA-JEFUL 1, 1, 5-19.

Raamdokument 2007 = Euroopa keeleõppe raamdokument: õppimine, ópetamine ja hindamine. Tartu: Haridus- ja Teadusministeerium, Eesti Rakenduslingvistika Ühing.

Ratassepp, Maria (2005) „Vene abiturientide vead eesti keele verbirektsioonis.” Teoses Raili Pool, toim. Teine keel, 111-134. (Tartu Ülikooli eesti keele (võõrkeelena) õppetooli toimetised, 5.) Tartu: Tartu Ülikooli Kirjastus.

Ringbom, Håkan (2007) Cross-linguistic similarity in foreign language learning. Clevedon: Multilingual Matters LTD.

Robinson, Peter (2005) „Cognitive complexity and task sequencing: Studies in a componential framework for second language task design". International Review of Applied Linguistics in Language Teaching (IRAL) 43,1, 1-32.

Salamoura, Angeliki ja Nick Saville (2010) „Exemplifying the CEFR: criterial features of written learner English from the English profile programme". Teoses Inge Bartning, Maisa Martin ja Ineke Vedder, toim. Communicative proficiency and linguistic development: intersections between SLA and language testing research, 101-132. (Eurosla Monograph Series, 1.) Kättesaadav aadressil $<$ http://eurosla.org/monographs/EM01/EM01home.html>. Vaadatud 01.05.2014. 
Skehan, Peter (1996) „Second language acquisition and task-based instruction”. Teoses Jane Willis ja Dave Willis, toim. Challenge and change in language teaching, 17-30. Oxford: Heinemann.

Skehan, Peter (1998) A cognitive approach to language learning. Oxford: Oxford University Press.

Skehan, Peter (2003) „,Task based instruction”. Language Teaching 36, 1, 1-14.

Spoelman, Marianne ja Marjolijn Verspoor (2010) „Dynamic patterns in development of accuracy and complexity: A longitudinal case study in the acquisition of Finnish”. Applied Linguistics 31, 4, 532-553.

Yuan, Fangyuan ja Rod Ellis (2003) „The effects of pre-task planning and on-line planning on fluency, complexity and accuracy in L2 oral production". Applied Linguistics $24,1,1-27$.

\begin{abstract}
Mare Kitsnik: Written learner language verb forms at B1 and B2 levels. CEFR (The Common European Framework) is the basis of teaching and assessment of second language (L2) in Europe. In the CEFR functional specifications of the L2 proficiency levels are given, which are universal for all languages. These specifications need to be completed with language specific linguistic descriptions. In this article the investigation of the linguistic content of the B1 and B2 levels of Estonian as a second language is described according to the CAF triad dimensions: complexity, accuracy and fluency. The presence of verb forms in the national examination texts (stored in the Estonian Interlanguage Corpus) on the both levels has been studied by using corpusdriven approach and the DEMfad model. Common verb forms on the B1 and B2 level have been identified. The verb tahtma 'to want', 'to wish' has been investigated more precisely; the distribution, frequency and accuracy of its constructions on the B1 and B2 level have been investigated. The main similarities and main differences between the levels are analyzed comparatively.
\end{abstract}

Keywords: second language acquisition, Estonian as a second language, CAFtriad, linguistic description of the B1 and B2 levels, written learner language, verb forms 